\title{
Development of Student Participation Instruments in Politics for Civic Education Learning in the University
}

\author{
Parji $^{1, *}$, Yoga Ardian Feriandi ${ }^{2}$ \\ ${ }^{1}$ Social Studies Education, Universitas PGRI Madiun, Madiun, 63118, East Java, Indonesia \\ ${ }^{2}$ Pancasila and Civic Education, Universitas PGRI Madiun, Madiun, 63118, East Java, Indonesia
}

Received January 6, 2020; Revised May 20, 2020; Accepted May 28, 2020

Copyright $(2020$ by authors, all rights reserved. Authors agree that this article remains permanently open access under the terms of the Creative Commons Attribution License 4.0 International License

\begin{abstract}
This research aims to develop instruments to measure the learning outcomes of Citizenship Education at the university level in the form of citizen political participation based on digital citizenship. The basis for developing instruments is the absence of benchmarks that can be used to measure the learning outcomes of citizenship education in the form of political participation behavior outside the classroom. This research uses R\&D steps, stage 1. Preliminary research, 2. research development, 3. Measurement effectiveness of the model, and 4. dissemination. Expert assessment results for content and content validation tests state that instruments of political participation based on digital citizenship are deemed appropriate with a CVI value of 1 (Relevant). While Analysis of a wide-scale questionnaire items obtained with the results of 26 valid questionnaire items with a reliability value of 0.98 . From the results of this analysis, the instrument is considered relevant to be used to measure education learning expenditure citizenship in the form of participation Politic residents in the modern era.
\end{abstract}

Keywords Student Political Participation, Instruments, Digital Citizenship, R\&D

\section{Introduction}

Citizenship education is a unique and particular subject in Indonesia. In the structure of the primary education curriculum up to universities in Indonesia, which requires citizenship education, is always there. One reason for civic education is that compulsory subjects is to increase political participation, especially for young citizens who pursue formal education. The role of civic education as part of political education is to help reduce gaps in political knowledge that should be provided by families (Neundorf, Niemi, \& Smets, 2016). Differences in the political education of each family occur due to various things, such as education level, and economic level. A research conducted by Kenneth P. Langton and M. Kent Jennings (2006), show the higher the education level of parents, the better political education provided by parents to children. While the economic level triggers, parents are able to offer various facilities that can increase their child's political knowledge.

Universities have more burden compared to other lower education levels. That is because the University educates mature citizens to participate in the political field. Associated with the results of citizenship education learning in the field of political participation, lecturers need to look at research statistics which show that 800 respondents students who spend 3-5 hours per day to do activities online using a computer (Junco \& Mastrodicasa, 2007). Internet usage for students can be at taking advantage of learning to use civic education, Increase political participation. From the research (Hyun \& Kim, 2015; Vettehen, Hagemann, \& Van Snippenburg, 2004) it is known to be developing technology that can take an important role to improve Student political participation with the surrounding environment. So learning citizenship education is necessary to synergize with technology that can later form digital citizenship, which means that learning can create citizens who can have a role active both directly in the community and indirectly through the digital world.

To synergize the learning of citizenship education with the technology of citizenship education lecturers use learning with a concept called "digital citizenship." Learning by using "Digital Citizenship" teaches students to use technology to carry out their obligations as citizens. In the implementation, a lecturer can choose the issues of citizenship such as law, politics, poverty, etc. that exist in society, and then ask students to find solutions to these problems. In the stages of completing the assignment, students start looking for information using the internet, 
and then come to conclusions in the form of solutions which will also be published using the internet so that they can be seen by the wider community. From the habit of using technology in learning to overcome various social problems, it can build students to have digital skills and skills and information processing skills (Young \& Gates, 2014).

Technology can also lead to a transformation of forms of student political participation, from the past to the modern era. Political involvement in the past demanded the direct role of students such as demonstrations, debates, participating in voting, holding regular meetings with the environment. Whereas in the modern form of student political participation can be done digitally (Skoric, Zhu, Goh, \& Pang, 2016) Even with the internet, students can contribute significantly to controlling social life in their environment. For example by giving criticism and petitioning, raising social funds in digital form / via the internet, and trying to solve social problems that occur in society using the internet (Grizzle, Alton; Moore, Penny; Dezuanni, Michael;Asthana, Sanjay; Wilson, Carolyn; Banda, Fackson; Onumah, 2013; Kuzu, Abdullah; Odabasi, Ferhan; Gunuc, 2015).

The measurement of citizenship education learning outcomes in tertiary institutions in Indonesia in the area of political participation, lacks focus, and is just like knowledge (Interview of Civics Education Lecturers) and is limited to classrooms. Some of the lecturers considered that measuring participation was massive, they only met directly with students on campus, whereas political participation did not only take place on campus but could be done digitally or with the help of technology. Also, there are some opinions which say that there is a gap between the citizenship knowledge obtained by students through citizenship education, and the behavior displayed by students in the community (Samsuri, 2010).

Pre-existing measurement instruments for measuring political participation, such as Henry E. Brady, (1995); Putnam (2016) Can be used but may not be relevant to the current student's condition. Nowadays, students are getting closer to technology so that they will do more political participation through technology. Although there is also an assumption that technology is the cause of decreased student involvement, the rapid development of technology makes society, including students, connected to it in social life (Putnam, 2016). The decline in student involvement is because technology can be understood because technology can make people complacent with social activities and make someone trapped in solitude (Boulianne, 2015). Various kinds of technological superiority, in the end, make students choose to interact with technology compared with fellow humans directly.

In addition to the instruments described above, there are other instruments of political participation created by Talo \& Manarini (2015). This instrument has four parts. The first part is formal political participation, which is about public involvement with the government officially. The second part, activism, is measured on these indicators, such as boycotting products, signing petitions, holding demonstrations. The third part is about people's interest in politics, writing news or articles about politics, buying newspapers, or looking at political communication in the media. The fourth is the release of this indicator related to students' reluctance to carry out activities related to politics, for example, such as not participating in voting, withdrawing from political talks, not reading news about politics. The weakness of their instruments is that they do not mention the time of participation. From this article, we hope to create instruments to measure the outputs of citizenship education learning in the form of better political participation than previously existing instruments

\section{Methodology of Research}

This research is research and development (Research and Development). Research development or Research and Development (R\&D) Research used in the adaptation of Borg \& Gall (2003). The product produced from this research is PPBD instrument. The research steps are grouped into 4 phases: Export Phase (Need Assessment, field research) The development phase consists of (instrument design, validation, revision, instrument draft, FGD, revision, Instrument Prototype) Testing phase (small-scale trials, revisions, RASCH Model Analysis, correction, extensive testing, feasibility analysis, change, final instrument) Dissemination (Implementation of Instrument measurements, analysis of measurement data, and interpretation of measurement results). Development activities are limited to the testing phase (wide-scale trials) related to limited research time. The research was conducted at four universities, with a random sample of 197 students who had completed a citizenship education course

\section{Results and Discussion}

The results of the discussion fund are divided into four phases, according to the methodology used in this research. Following is an explanation of each phase:

\section{Phase 1 (Exploration Phase).}

Phase 1 is the activity of identifying needs and assessing why the instruments of student participation in politics for learning civic education at the university level, as well as evaluating and gathering the essentials needed to compile these instruments through surveying the conditions of citizenship education directly in the field.

In interviews with citizenship education lecturers at four universities spread across Java, Indonesia, they were 
convinced that political knowledge could be obtained properly. But they are also not sure about the knowledge about politics that these students gain that they can directly practice in the community. And three citizenship education lecturers can only measure it in the field of knowledge about politics. Therefore, they need help to be able to measure the behavior of their students as a result of learning civic education more broadly and not limited to the classroom.

After the field survey, this stage is then followed by a literature review, to formulate the indicators needed to develop instruments for political participation. The following are the results of the literature review expressed in the indicators of political participation:

\section{Student political participation}

Politic participation is the willingness of student to engage in civil society, community and political life, characterized by mutual respect and non-violence and following human rights and democracy (Hoskins \& Mascherini, 2009). There are two models of political participation, namely: Conventional and Unconventional. In the Conventional model political participation is carried out through direct activities such as elections, political speeches, voting, Political Discussions, paying taxes, obeying regulations, Forming and joining interest groups, and Communication with governmental officials. This model of political participation has been around for quite a long time, precisely since the 1940s and 1950s. Unconventional is a mode of political participation that grows along with the emergence of the New Social Movements. In this new social movement there emerged a pro-environmentalist movement, a feminist wave of women's campaigns, student pro, tests and terror, filing petitions, demonstrating, confrontation, striking, acts of political violence against property, guerrilla warfare and revolution (Verba and Almond 1980; Ramlan 1992).

In its development, in society, the form of participation Conventional develops into Unconventional. The development of this form of involvement is due to various things, one of which is the result of technology, and the political participation that could only be carried out directly now can be done more efficiently and without limits. From here, there will be two forms of political participation, namely: traditional and modern political participation. A traditional way is a form of participation that has long been practiced by the community, such as demonstrations, attending meetings with the environment, and listening to speeches while the structure of modern participation consists of various new forms of political participation such as: making petitions online, communicating politically online. To be more transparent, we present a comparison of modern and traditional political participation in table 1 below.
Table 1. Changes in the form of traditional participation become modern

\begin{tabular}{|c|c|c|c|}
\hline & & Tradisional & Modern \\
\hline $\begin{array}{c}\text { GENERAL/ } \\
\text { TRADITIONAL }\end{array}$ & & \begin{tabular}{l|} 
Institutional \\
framework \\
Regular, formal \\
Voting, activities \\
within political \\
parties, contacting \\
politicians etc.
\end{tabular} & $\begin{array}{ll}\text { - } & \text { Civic framework } \\
\text { - } & \text { Sporadic, } \\
\text { informal } \\
\text { - } \\
\text { Forms of protest, } \\
\text { political } \\
\text { consumerism, } \\
\text { mobilisations etc. }\end{array}$ \\
\hline $\begin{array}{l}\text { DIGITAL/ } \\
\text { ONLINE }\end{array}$ & & $\begin{array}{l}\text { Extended to online } \\
\text { forms of } \\
\text { communication and } \\
\text { digital media } \\
\text { Institutionalised } \\
\text { context } \\
\text { E-voting, browsing }\end{array}$ & $\begin{array}{ll}\text { - } & \text { Extended to } \\
\text { online } \\
\text { communication } \\
\text { and digital media } \\
\text { - } \quad \text { Civic context } \\
\text { Online protest, } \\
\text { online }\end{array}$ \\
\hline
\end{tabular}

At the student level, political participation can be looking in the form of student participation in various programs created by the university. Besides, they can also protest and advise on policies issued by the university, for example, participation by students such as opposing school fees, campus regulations, etc. Student participation can also be done through citizenship education learning through citizenship projects. In the citizenship project, "we are people," students are invited to observe the surrounding environment, and then find a solution to this problem. Not only finding solutions but, in this project, students also ask related parties to solve existing problems (Morgan 2016) together. In studying citizenship education, there are teaching methods that are considered superior, and are based on the "We Are The People" citizenship project. The "We Are The People" method is considered by various experts to increase student political participation (Vontz, Thomas S.; Metcalf, Kim K.; Patrick 2000). However, in measuring the methodology of the "We are the people" citizenship project, it is also limited to classrooms and the value of portfolio results made by students (Mulyoto and Samsuri 2017). So that the presence of this instrument will also be able to equip citizenship education teachers who want to use civil engineering methods "we are people."

From various theories put forward by(Henry E. Brady 1995; Ramlan 1992; Fink and Črnič 2014) then we can simplify some indicators that can be used to obtain student political participation, and some of these indicators are Campaigns, supporting voices, Political Discussions, Forming and combining in interest groups, Communication with governmental officials, and Protest

\section{Political Campaign}

The campaign is a communication activity that is planned to produce an impact on a broad audience, and campaigns are also carried out continuously but with a specified period (Venus 2009). In this case, the expected effects related to politics, such as changes in regulations, changes in officials government, or about social problems that exist in the community. Campaign according to Venus 
2009 includes four things, namely;

1. To make specific effects or impacts;

2. large campaign targets;

3. Performed at a particular time;

4. Organized.

To be said as a campaign, an activity needs to fulfill several indicators such as: having a goal to influence the same thing; planned; and sustainable. At this time the campaign can be carried out with the help of technology; for example, using the WhatsApp status update feature; "Facebook"; "Twitter"; or other social media and messaging; someone can campaign and become the target of the campaign. The campaign with technology is sometimes not realized by the millennial generation, although it only sees status updates from social media that have a message to influence those views, including campaigns.

\section{Voting}

Polling has become one of the methods used to determine important decisions for the community. The vote is used starting from the smallest level of society, namely the family to the state level (Kahani 2006). Polling functions to gather aspirations and find the best solutions to solve problems in the community, where the number of votes becomes a very decisive outcome of the outcome of solving a problem through Polling. So that coming to a polling station/polling place is an indicator that can reflect community participation, but just entering and participating in polls is not enough to be the basis for high low community participation; they may not occur during elections, but maybe they care more by voting through other e-voting containers for example. With the development of technology, it allows people to do e-voting, namely the method of voting and vote counting in elections using electronic devices (Priyono and Dihan 2010). Electronic or digital forms are used in various stages of elections starting from the registration process, voting, to vote to count in (Rohman ALi 2011). For example, people can control government policies by using polls through online petitions. For example, the phenomenon that occurred in Indonesia regarding the operation of the "PT Freeport" mine operating in "Papua," many Indonesians wanted the Indonesian government to take over the shares of "PT free port." Many of the people made polls via the internet "www.change.org" in the hope that the Indonesian government would hear their wishes.

From this point of view, we need to review the voting indicator, not only about coming to polling stations but also about delivering aspirations in other, more modern ways. So that some of the right keywords to measure the willingness of people to choose or choose are: aware and not forced, have specific goals, try to influence public policy.

\section{Politic discussion}

The purpose of the discussion is to reach consensus among each group member, and by discussing decision making it will be easier because there will be various types of information from discussion participants (Stasser and Titus 2006). So that the assessment of community activities is related to political discussion, many of which value their presence in various direct forums/meetings in the community. For example, (Putnam 2016) states that the society began to feel unwilling to attend meetings, discussions, and finally concluded that the interest of the community to engage in public discussions started to decline.

However, keep in mind that in this era, various media such as the internet, newspapers, radio, and television can influence multiple changes in people's attitudes (Vaccari 2010; Voltmer 2005). Even in democracies, media can fill deficiencies and strengthen democratic processes (Curran 2014; Downing 2007; Splichal 1994). The disadvantage is that, without the press, it is difficult for the public to get the latest information about social problems in their country, so they do not participate directly to help overcome existing social issues.

However, it is easy to access the media, making people more interested in specific issues and political ideas which in the end can arouse citizens' political awareness, and even with internet media people can easily carry out political communication with various stakeholders (Farrell 2012). The internet and other social media such as Facebook, Twitter, e-mail are used by young people as a forum for political discussion and debate, giving opinions and sharing information.

From here, if concluded, several keywords can measure indicators of political discussion, and these keywords are: there is two-way communication, trying to solve social problems, carried out consciously and voluntarily.

\section{Form and join interest groups}

Joining social groups is essential. Even according to some studies, social groups are factors that can support the creation of "Civil Society" (Syed Hussein, 1987). In the development of this social group, it is not only groups that have regular meetings in the same place. Social groups also include digital groups that do not directly meet but actively carry out activities and discussions via the internet (Yasmin, 2013). For example: social-religious groups in Egypt, Libya, and Syria. For young people who are not old enough, they choose to voice their aspirations about religion through various digital groups in their countries (Yasmin, 2013). Associated with political participation, social groups also allow people to control policies carried out by the government, or other parties related to the interests of society.

Discussions addressing the issue of student political 
participation have long been carried out. But so far, there is no right solution to increase student citizenship participation. Ha, Joa, Gabay, \& Kim, (2018) argues that engagement through the online world is more acceptable to students in the current era. However, student activities through campus organizations often trigger a tendency to lead to political participation. Because basically, student activities in organizations make them think complex (Altbach, 2007). Even in some countries, students are determinants of political change. In Chile, the Student Movement can collect political reforms (Donoso, 2016). In Indonesia, the 1998 reforms emerged when economic conditions in Indonesia became increasingly illogical. Even students often reject Suharto's election as president for the seventh time (Galih, 2018). In certain circumstances in America, students are an important political element (Lipset \& Altbach, 2016). Related to political participation, interest groups also allow the public to control policies carried out by the government, or other parties related to community interests.

\section{Communication with public officials}

Communication is simply a transfer of information and understanding from someone to others (Andrew E 1981). Flippo (2009) argues that communication is an activity that causes other people to interpret an idea, primarily what is intended by the speaker or writer. The interface has several forms, such as verbal and nonverbal communication. Oral is communication that uses sound or uses writing, while non-verbal means communication using signals or expressions. Regarding political officials, communication is the delivery of information from the public about the surrounding conditions to government officials. At the student level, communication with school officials or teachers is also part of political communication.

With the development of technology, communicating with officials can not only be done directly, such as when there are dialogues with officials such as those measured by Putnam (2016), currently communication can be carried out with social media assistance, for example, West Java Guberman Ridwan Kamil Malik who actively communicates with his citizens via the internet (Wulansari 2014). From that, the communication of political officials can be characterized by there is an exchange of information, carried out verbally and non-verbally, using the media.

\section{Development Phase}

At the development stage, the development of the instrument is carried out using indicators from the results of a literature review. After the draft instrument, there was a focus group discussion (FGD) to get advice from political experts and citizenship education learning.

\section{Focus Group Discution (FGD)}

This FGD involved citizenship education lecturers and also lecturers who taught political science subjects. After the FGD, the researchers got several suggestions for improvement of the instrument. These tips include too many items and a lack of negative statement items. After revision, the next draft instrument was tested again by experts in learning and politics.

The points of the instruments tested were 28 question items, which were then sent to be tested by experts / Judge Experts, which in this research involved five experts who assessed the feasibility of instruments. Experts are chosen because they have knowledge that is under this field of research, which is about political participation. from the expert analysis, the next step was analyzed using the CVR method. With equations (Wilson, Pan, and Schumsky 2012)

$$
\operatorname{CVR}=\frac{n_{e}-\left(\frac{N}{2}\right)}{\frac{N}{2}}
$$

From the Eq.1, then the analysis and results will be compared with the following table values.

Table 2. Minimum CVI Analysis score based on the number of experts

\begin{tabular}{|c|c|}
\hline Number of expert Judgement & Minimum score \\
\hline 5 & 0,736 \\
\hline 6 & 0,672 \\
\hline 7 & 0,622 \\
\hline 8 & 0,582 \\
\hline
\end{tabular}

The results of the analysis using CVR indicate that item number 27 gets a CVI value of 0.2 or less than the minimum score required (Table 2). Because number 27 does not meet the requirements, and then it is repaired, and then tested again (See Table 3). 
Table 3. Summary of the results of the instrumented assessment by experts

\begin{tabular}{|c|c|c|c|}
\hline Indicator & CVI & Item question & Review results \\
\hline \multirow[t]{4}{*}{$\begin{array}{l}\text { Political campaign } \\
\text { Student via the } \\
\text { internet }\end{array}$} & 1 & $\begin{array}{l}\text { In the past six months, have you been } \\
\text { following/listening to political campaign } \\
\text { activities through the internet? }\end{array}$ & $\begin{array}{l}\text { The five experts agree that this item is feasible to use in } \\
\text { research, and it is appropriate to measure the indicators set. This } \\
\text { item can measure passive Student political participation. The } \\
\text { campaign became a benchmark for one's concern regarding } \\
\text { public policies, especially using the internet. This indicator can } \\
\text { be a distinguishing factor as well as an instrument refinement of } \\
\text { the measurement of political participation that previously } \\
\text { existed because it included technological factors that were often } \\
\text { ignored and considered not political participation. }\end{array}$ \\
\hline & 1 & $\begin{array}{l}\text { In the past six months, have you seen political } \\
\text { campaigns through electronic / internet media? }\end{array}$ & $\begin{array}{l}\text { The five experts agree that this item is feasible to use in } \\
\text { research, and it is appropriate to measure the indicators set. }\end{array}$ \\
\hline & 1 & $\begin{array}{l}\text { In the past six months, have you ever posted } \\
\text { pictures/videos/ writings to change the political } \\
\text { views of others? }\end{array}$ & $\begin{array}{l}\text { One of the main things that influence political participation is } \\
\text { the level of individual concern for a policy, by posting } \\
\text { information to change the opinions of others, proving their } \\
\text { concern for public policy. Besides posting information to } \\
\text { influence the opinions of others also reflects the level of } \\
\text { knowledge of one's citizenship, which also affects political } \\
\text { participation in Student. The five experts concluded that this } \\
\text { item was worth using, to measure civic engagement. }\end{array}$ \\
\hline & 1 & $\begin{array}{l}\text { In the past } 6 \text { months, have I never posted a } \\
\text { picture/video/ article to change the views of } \\
\text { others? }\end{array}$ & $\begin{array}{l}\text { All expert validators argue that this item is worthy of use, but } \\
\text { one expert suggested that the indicator regarding the campaign } \\
\text { via the internet in point No. } 4 \text {, according to him, would be better } \\
\text { replaced by "forwarding the message or information you get to } \\
\text { other people." Besides, because this item tries to influence or } \\
\text { change people's views, it is appropriate to measure political } \\
\text { participation. A simple example is the number of people who } \\
\text { did not come during the general election, one of which was } \\
\text { caused by a lack of knowledge about the benefits and effects of } \\
\text { the vote. This opinion makes the five experts agree that this } \\
\text { item is worthy of being used as an instrument to measure } \\
\text { political participation. }\end{array}$ \\
\hline \multirow[t]{4}{*}{$\begin{array}{l}\text { Student Voting via } \\
\text { the internet }\end{array}$} & 1 & $\begin{array}{l}\text { In the last six months, have you given } \\
\text { criticism/advice to the government through the } \\
\text { internet? }\end{array}$ & $\begin{array}{l}\text { The five experts stated that this item is worthy of use, one of the } \\
\text { experts revealed the reason for its feasibility, namely because } \\
\text { criticism/advice to the government reflects the activeness of } \\
\text { citizens. This question can measurement goal of citizen } \\
\text { participation, namely the existence of feedback about various } \\
\text { things done by the government so that the nets of the } \\
\text { government will not become authoritarian, citizens have a role } \\
\text { to be active as government controllers. }\end{array}$ \\
\hline & 1 & $\begin{array}{l}\text { In the past } 6 \text { months, have you signed an online } \\
\text { petition? }\end{array}$ & $\begin{array}{l}\text { The five experts stated that this item was worthy of use, but one } \\
\text { expert noted that this item needed to be improved to make it } \\
\text { easier for respondents to understand, and suggested the } \\
\text { sentence be "I give aspirations through online mass media, } \\
\text { column comments, column aspirations, or readers' minds. " }\end{array}$ \\
\hline & 1 & $\begin{array}{l}\text { I signed the online petition last more than } 6 \\
\text { months ago! }\end{array}$ & $\begin{array}{l}\text { The five experts stated that this item was feasible to use, one } \\
\text { expert revealed its feasibility because the petition is one of the } \\
\text { direct forms of citizen political participation in a modern form, } \\
\text { in the past form such collection can only be done directly. }\end{array}$ \\
\hline & 1 & $\begin{array}{l}\text { In the last six months have you tried to voice } \\
\text { your opinion on the internet? }\end{array}$ & $\begin{array}{l}\text { One expert validator suggested that Item number eight } \\
\text { questions were suitable for use, but needed revised sentences. } \\
\text { The advice given by the expert validator is to change this } \\
\text { sentence to "in the past six months I have participated in } \\
\text { responding to online media related to politics" to make it easier } \\
\text { for respondents to understand while the other four stated that } \\
\text { this item was suitable for use. }\end{array}$ \\
\hline \multirow[t]{2}{*}{$\begin{array}{l}\text { Students conduct } \\
\text { Political } \\
\text { Discussions via the } \\
\text { internet } \\
\end{array}$} & 1 & $\begin{array}{l}\text { In the last six months have you commented on } \\
\text { the topic of politics on the internet? }\end{array}$ & $\begin{array}{l}\text { The five experts stated that this item shows the concern of } \\
\text { citizens related to a state policy, which is a reflection of } \\
\text { political participation so that it is feasible to be used to measure } \\
\text { digital political participation. }\end{array}$ \\
\hline & 1 & $\begin{array}{l}\text { In the last six months, did you speak/discuss } \\
\text { with your friends about politics using internet } \\
\text { media? }\end{array}$ & $\begin{array}{l}\text { According to the expert, the intensity of political development } \\
\text { shows the level of knowledge of citizenship and their } \\
\text { awareness on issues of citizenship. So that the five experts } \\
\text { agreed to state that this item is worthy of use }\end{array}$ \\
\hline
\end{tabular}




\begin{tabular}{|c|c|c|c|}
\hline & 1 & $\begin{array}{l}\text { I am always lazy and avoid compilation and are } \\
\text { invited to talk about politics six months ago! }\end{array}$ & $\begin{array}{l}\text { The five experts stated that this item is worthy of use because it } \\
\text { can judge whether someone has a concern with political issues } \\
\text { or not. }\end{array}$ \\
\hline & 1 & $\begin{array}{l}\text { In the past six months, have you debated, or } \\
\text { argued against government policies with your } \\
\text { friends through social media? }\end{array}$ & $\begin{array}{l}\text { The five experts agree that this item is feasible and can be used } \\
\text { to measure digital political participation. }\end{array}$ \\
\hline \multirow{4}{*}{$\begin{array}{l}\text { Student Form and } \\
\text { join interest groups } \\
\text { through the } \\
\text { internet }\end{array}$} & 1 & $\begin{array}{l}\text { In the last six months, have you joined a } \\
\text { particular community/association online? }\end{array}$ & $\begin{array}{l}\text { The five experts agree that this item is feasible and can be used } \\
\text { to measure digital political participation. }\end{array}$ \\
\hline & 1 & $\begin{array}{l}\text { In the last six months, did you follow the } \\
\text { community digitally/not meet directly with } \\
\text { other members and only interact using the } \\
\text { internet? }\end{array}$ & $\begin{array}{l}\text { The five experts agree that this item is feasible and can be used } \\
\text { to measure digital political participation. }\end{array}$ \\
\hline & 1 & $\begin{array}{l}\text { In the past six months, I have separated myself } \\
\text { from various existing interest groups! }\end{array}$ & $\begin{array}{l}3 \text { out of } 5 \text { experts suggest that Item } 15 \text { is feasible to use but is } \\
\text { recommended to be improved so that it is easier to understand } \\
\text { and does not cause multiple interpretations. }\end{array}$ \\
\hline & 1 & $\begin{array}{l}\text { I In the last six months, have you made a move } \\
\text { on the internet to fight for a particular social } \\
\text { goal? }\end{array}$ & $\begin{array}{l}\text { This item is suitable for use because it can reflect the form of } \\
\text { direct citizen participation. So that the five experts concluded } \\
\text { that this item was worth using }\end{array}$ \\
\hline \multirow[t]{4}{*}{$\begin{array}{l}\text { Students } \\
\text { communicate with } \\
\text { political officials } \\
\text { via the internet. } \\
\end{array}$} & 1 & $\begin{array}{l}\text { In the past six months, have you expressed your } \\
\text { hopes/opinions to government officials } \\
\text { directly? }\end{array}$ & The five experts concluded that this item was worth using. \\
\hline & 1 & $\begin{array}{l}\text { In the last six months, have you tried to convey } \\
\text { your aspirations to the legislative / government } \\
\text { members through social media? }\end{array}$ & The five experts concluded that this item was worth using. \\
\hline & 1 & $\begin{array}{l}\text { I have never participated in social media } \\
\text { political officials! }\end{array}$ & $\begin{array}{l}\text { Item no. } 19 \text { is recommended to be changed to "whether in the } \\
\text { last six months often post political arguments and then mark the } \\
\text { political officials involved in the post. }\end{array}$ \\
\hline & 1 & $\begin{array}{l}\text { In the past six months, have you followed / } \\
\text { followed political officials through your social } \\
\text { media? }\end{array}$ & $\begin{array}{l}\text { This can address the real efforts of a citizen towards political } \\
\text { participation, by simply playing / following social media from } \\
\text { political officials, one can obtain up to date information related } \\
\text { to politics. }\end{array}$ \\
\hline \multirow[t]{4}{*}{$\begin{array}{l}\text { Students protest } \\
\text { through the } \\
\text { internet. }\end{array}$} & 1 & $\begin{array}{l}\text { In the last six months, did you protest the } \\
\text { government's policy of using the internet? }\end{array}$ & The five experts concluded that this item was worth using. \\
\hline & 1 & $\begin{array}{l}\text { I prefer to keep quiet and carry out all } \\
\text { government policies even though I don't agree }\end{array}$ & $\begin{array}{l}\text { item no. } 22 \text { was changed to "I gave a protest related to the } \\
\text { policy that was carried out by the government and provided an } \\
\text { alternative solution" }\end{array}$ \\
\hline & 1 & $\begin{array}{l}\text { In the last } 6 \text { months, have you protested / } \\
\text { complained about public facilities through } \\
\text { social media? }\end{array}$ & $\begin{array}{l}\text { Item number } 23 \text { was changed to "do I invite friends or } \\
\text { community to sign petitions related to government policies } \\
\text { online" }\end{array}$ \\
\hline & 1 & $\begin{array}{l}\text { I never protested / or showed an attitude of } \\
\text { agreeing to a policy made by the government } \\
\text { through the internet! }\end{array}$ & The 5 experts concluded that this item was worth using \\
\hline \multirow[t]{4}{*}{$\begin{array}{c}\text { Students submit } \\
\text { petitions via the } \\
\text { internet }\end{array}$} & 1 & $\begin{array}{l}\text { In the last } 6 \text { months, have you submitted or } \\
\text { made a petition? }\end{array}$ & The 5 experts concluded that this item was worth using \\
\hline & 1 & $\begin{array}{l}\text { I think making and signing a petition is } \\
\text { something that is in vain }\end{array}$ & $\begin{array}{l}\text { This item is appropriately used to measure the political } \\
\text { participation of citizens based on digital citizenship (LPDC), by } \\
\text { thinking that the submission of a petition is a futile matter that } \\
\text { can portray someone who has begun to be indifferent regarding } \\
\text { government policies and finally decides not to be involved in } \\
\text { politics. }\end{array}$ \\
\hline & 1 & I never filled a petition! & $\begin{array}{l}2 \text { out of } 5 \text { experts agree that this item is better removed, but } 3 \\
\text { experts suggest revision because the words are } \\
\text { multi-interpreted and do not describe specifically what they } \\
\text { want to measure. So the final decision is to delete this item. }\end{array}$ \\
\hline & 1 & $\begin{array}{l}\text { In the last } 6 \text { months, have you made / signed an } \\
\text { online petition like on web cange.org? }\end{array}$ & $\begin{array}{l}\text { The five experts stated that this item was worthy of use, but } 2 \\
\text { experts suggested revising, } 2 \text { experts argued that this item } \\
\text { directed respondents to use the website "change.org" even } \\
\text { though online petitions could not only be made through the } \\
\text { website alone. }\end{array}$ \\
\hline
\end{tabular}


Table 4. The results of the class test statistic analysis are limited

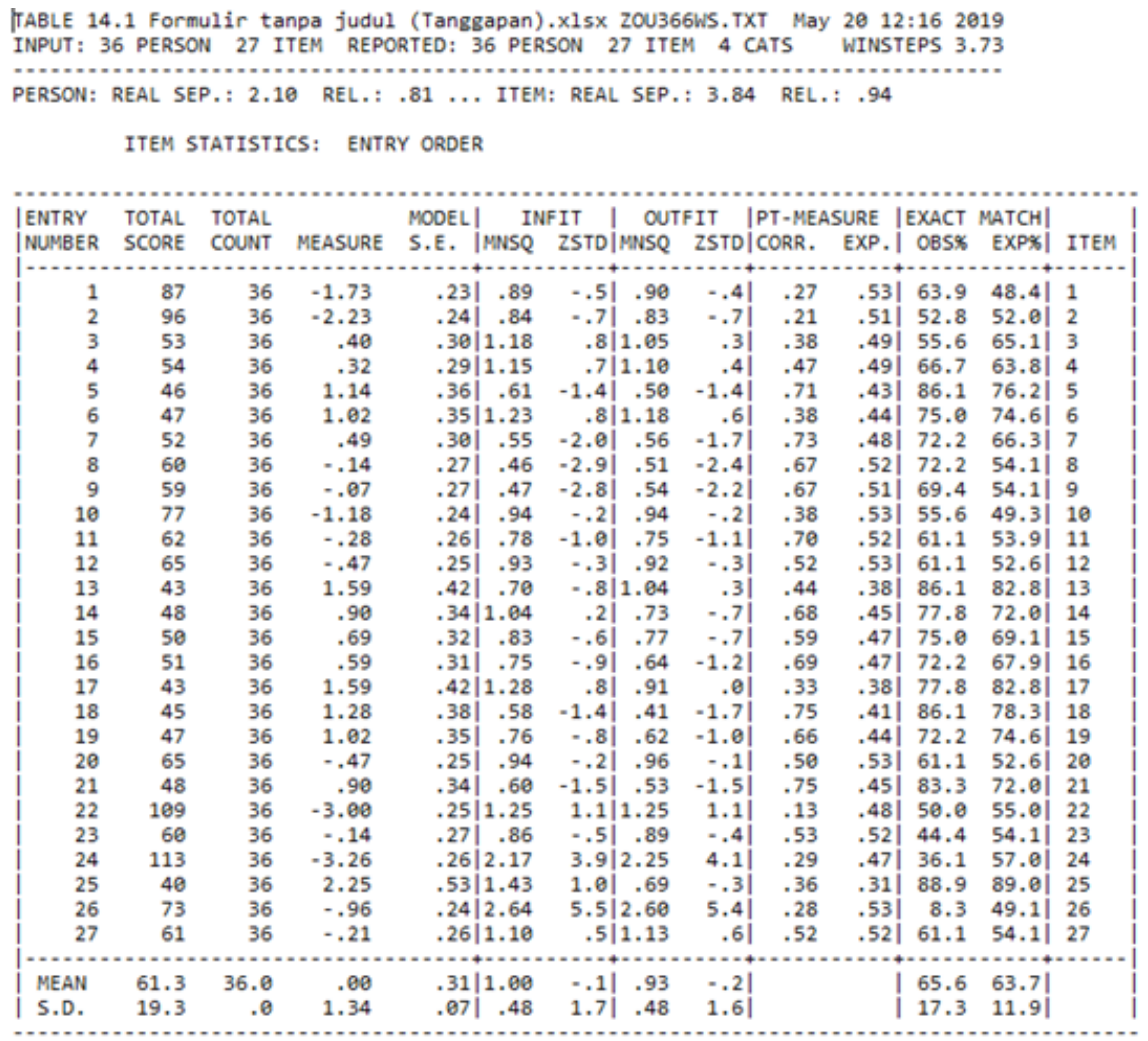

\section{Testing Phase}

\section{Small Scale Test}

After going through an expert test, the next step is to revise the item according to expert advice and do a small scale test. In this test, the items were given to students totaling 36 people, then analyzed using RASH Model, with the help of Winstep software. Results from small-scale tests can be seen from the table 4 above.

According to (Boone, William J; Staver, John R; Yale 2014) the value of means-square outfit, z-standard outfit, and point measure correlation are the criteria used to see the item's suitability level. If the item does not meet the requirements, there is a good thing that the item is repaired or replaced. Guidelines for assessing grain suitability criteria according to (Boone, William J; Staver, John R; Yale 2014) are as follows.

Received Mean Square (MNSQ) Outfit value: 0.5 $<$ MNSQ $<1.5$

The Z-standard (ZSTD) outfit value received: -2.0 $<$ ZSTD $<+2.0$

Value Point Measure Correlation received: $0.4<$ pt corr measure $<0.85$

Because point measure correlation in principle is the same as point-correlation correlation in classical test theory,
Keeves \& Alagumalai, (2005) classify the value of Point Measure Correlation to be very good $(>0.40)$, good (0.300 , 39), sufficient $(0.20-0.29)$, unable to discriminate $(0,00-0,19)$, and require examination of items $(<0,00)$. So if we compare it with the results of the data analysis above, the questions that need to be fixed are only at number 22 .

\section{Testing}

\section{Broad Scale Test}

For a wide-scale test, the instrument was tested by 197 students from four University, and conducted online using google form. These results are then analyzed using the RASH Model, with the help of Winstep software. The results of this wide-scale test can be seen from the table 5 below.

Seeing the results of the statistical tests in table 2 and 5, there is one invalid item, namely item no. 24 and 21, because the value is still MNSQ outside of $0.5<$ MNSQ $<1.5$. Besides, the results also show that the assumption of this research is proven, namely there is a tendency for the transition from the form of political participation to the digital form. It can be marked from several question items such as listening to political campaigns (item no. 1), and regarding online communities (items no. $13 \& 14$ ) that many respondents did. From these results it can also be known that the level of reliability produced is equal to 0.98 . 
Table 5. The results of this wide-scale test

\begin{tabular}{|c|c|c|c|c|c|c|c|c|c|c|c|c|c|}
\hline ITRY & TOTAL & TOTAL & & MODELL| & & FIT & ou & FIT & |PT -ME, & SURE & |EXACT & MATCH| & \\
\hline MBER & SCORE & COUNT & MEASURE & S.E. & IMNSQ & ZSTD & IMNSQ & ZSTD & ICORR. & EXP. & OBS\% & EXP\$I & Item \\
\hline 1 & 456 & 198 & -1.39 & .09 & .75 & -3.1 & .83 & -1.9 & .52 & .55 & 56.1 & 46.2 & no 1 \\
\hline 2 & 497 & 198 & -1.74 & .09 & .68 & -4.1 & .72 & -3.4 & .53 & .54 & 62.1 & 46.5 & no 2 \\
\hline 3 & 287 & 198 & .40 & .12 & 1.00 & .0 & .86 & -1.0 & .61 & .48 & 69.7 & 66.3 & no 3 \\
\hline 4 & 276 & 198 & .58 & $.13 \mid$ & 1.23 & 1.8 & 11.06 & .4 & .49 & .47 & 70.7 & 68.9 & no 4 \\
\hline 5 & 311 & 198 & .06 & $.11 \mid$ & 1.00 & .0 & .96 & -.2 & .55 & .51 & 56.6 & 59.4 & no 5 \\
\hline 6 & 263 & 198 & .81 & $.14 \mid$ & 1.17 & 1.3 & .95 & -.3 & .49 & .45 & 76.8 & 71.9 & no 6 \\
\hline 7 & 296 & 198 & .26 & .12 & .73 & -2.6 & .69 & -2.6 & .62 & .49 & 73.7 & 63.0 & no 7 \\
\hline 8 & 349 & 198 & -.39 & .1 & .78 & -2.4 & .74 & -2.7 & .6 & .53 & 59.6 & 50.7 & no 8 \\
\hline 9 & 356 & 198 & -.46 & .10 & .67 & -3.8 & .65 & -3.9 & .70 & .54 & 56.6 & 50.4 & no 9 \\
\hline 10 & 428 & 197 & -1.16 & .09| & .76 & -2.9 & .77 & -2.7 & .63 & .55 & 51.3 & 46.6 & no 10 \\
\hline 11 & 328 & 198 & -.15 & .11 & .73 & -2.8 & .72 & -2.7 & .6 & .52 & 63.1 & 55.8 & no 11 \\
\hline 12 & 398 & 198 & -.88 & .10 & .85 & -1.7 & .84 & -1.8 & .6 & .55 & 40.9 & 45.8 & no 12 \\
\hline 13 & 255 & 198 & .98 & .15 & | 1.17 & 1.2 & .78 & -1.3 & .63 & .43 & 79.8 & 74.9 & no 13 \\
\hline 14 & 284 & 198 & .45 & .13 & 1.05 & .5 & .88 & -.8 & .57 & .48 & 65.7 & 66.8 & no 14 \\
\hline 15 & 313 & 198 & .03 & $.11 \mid$ & 1.00 & .1 & 11.07 & .6 & .5 & .51 & 64.6 & $58.3 \mid$ & no 15 \\
\hline 16 & 296 & 198 & .2 & .12 & .85 & -1.3 & .72 & -2.3 & .6 & .49 & 70.2 & 63.0 & no 16 \\
\hline 17 & 271 & 198 & .66 & .13 & 1.10 & .8 & .90 & -.6 & .60 & .46 & 77.8 & 70.0 & no 17 \\
\hline 18 & 259 & 198 & .90 & .14 & .85 & -1.1 & .65 & -2.3 & .66 & .44 & 82.8 & 73.7 & no 18 \\
\hline 19 & 243 & 198 & 1.27 & . 16 & .95 & -.3 & .67 & -1.8 & .5 & .40 & 76.8 & 80.3 & no 19 \\
\hline 20 & 3 & 198 & -.58 & .10 & | 1.17 & 1.8 & 11.09 & .9 & .4 & .54 & 47.0 & 48.9 & no 20 \\
\hline 21 & 258 & 197 & .89 & .14 & .82 & -1.4 & .67 & -2.1 & .59 & .44 & 71.6 & 73.6 & no 21 \\
\hline 22 & 447 & 197 & -1.33 & .09 & 1.62 & 5.9 & 1.81 & 7.3 & .03 & .55 & 43.1 & 45.6 & no 22 \\
\hline 23 & 357 & 198 & -.47 & .10 & 1.20 & 2.0 & 1.17 & 1.6 & .38 & .54 & 52.5 & 50.4 & no 23 \\
\hline 24 & 364 & 198 & -.55 & .10 & 2.89 & 9.9 & 3.21 & 9.9 & -.02 & .54 & 35.9 & 49.0 & no 24 \\
\hline 25 & 229 & 198 & 1.71 & .19 & 1.24 & 1.3 & 1.16 & .7 & .27 & .35 & 83.3 & 85.8 & no 25 \\
\hline 26 & 340 & 198 & -.29 & $.11 \mid$ & .94 & -.6 & .96 & -.3 & .37 & .53 & 58.6 & 51.9 & no 26 \\
\hline 27 & 307 & 198 & .11 & .12 & .76 & -2.4 & .81 & -1.6 & .47 & .51 & 61.1 & 59.9 & no 27 \\
\hline & & 7.9 & .6 & & |1.04 & -.1 & .9 & -.6 & & & & & \\
\hline 3.0 & 68.8 & .3 & .84 & .02 & .42 & 2.9 & .50 & 2.9 & & & 12.7 & 11.6 & \\
\hline
\end{tabular}

From these results, it can be seen that these instruments have advantages when compared to instruments for measuring other political participation such as (Talò and Mannarini 2015; Putnam 2016; Henry E. Brady 1995). The advantage of this instrument is that it can accommodate the forms of modern political participation that can now be done through the internet, and has a specific period when such participation is carried out. However, this does not mean that this instrument can completely replace other existing instruments, but can be used to be accompanied and complementary. Another advantage of this instrument is the analysis process, which has used modern instrument analysis techniques (Rasch models), the advantages of this analytical technique that is item analysis to determine reliability are also done to the level of each instrument item. In addition to items, the Rasch model also simultaneously tests the person (respondent), who can show the respondent's pattern of consistent answers, who tends to approve (in the attitude instrument) and identify the answers that are just the origin. Tests for research instruments can also be carried out in the form of dimensionality tests, as well as detection of bias from the items being tested. So that the instrument can meet objective measurement requirements.

The instrument in the form of a questionnaire makes it easy for users (teachers/lecturers) to profile broad political participation in a relatively short time. In Indonesia, citizenship education teachers on average assess student behavior by observation, but actual observation will make the teacher burden increases. Moreover, the number of students observed is enormous. The number of students can make an objective and unbiased assessment. Besides, by observing student behavior directly, the teacher will be limited in assessing students on practices that appear only.

In contrast to the use of the questionnaire, the teacher will get data about objective behavior from students, from the accumulation of daily activities that have been carried out by students. With Questionnaire, there may be dishonesty among students in filling out the questionnaire, and this can be minimized by using negative instrument items and filling instruments without mentioning the complete identity of the respondent. The negative form of the instrument statement makes the respondent not to fill in with the same answer as the previous numbers. While filling in the instrument with no mention of identity makes students not feel anxious in answering the statements in the questionnaire, this can certainly make students more objective in answering. Although not mentioning the identity of at least the teacher can know the achievement of political education learning in groups in each class, this is important to do so that teachers can always improve the quality of their knowledge or evaluate the learning they have done for the better.

Although in filling out the questionnaire, the respondent did not mention identity, and the teacher did not know the achievements of each individual. By using the questionnaire, at least the teacher can see the results of political education in groups in each class. This is important so that teachers can always enhance the quality of their knowledge or evaluate the learning they have done in order to improve the quality of their knowledge.

Likert scale used in this instrument is also not without reason, and the results of a comparative study of behavioral measurement techniques (Split-half reliability; 
Spearman-Brown; Likert scale; the semantic differential measure, Guttman scale; Thurstone scale) conducted by Hill and Tittle (1967) concluded that Likert is the best technique that can be used to measure behavior. With Likert researchers will get data in the form of intervals that can be reviewed and analyzed widely (Jung 2005), in addition to the data generated Likert can also avoid assumptions (typical behavior / not ideal) and be able to display data according to reality (Jung 2005; Burgoon 1976). Therefore the application of Likert to measure students' political behavior is an appropriate decision, and this has become one of the strengths of this instrument.

Integrating technology in instruments also speeds up instrument data processing. Lecturers can easily collect data from many students at once quickly and are easy for further analysis. Even instruments can also be distributed to all schools in an area to find out the political participation of young people in that place. For example, in the trial phase of this instrument, data is retrieved using Google forms. From Google forms, researchers can obtain data from four campuses that are more than $200 \mathrm{~km}$ adrift in just one week.

The technology element that was deliberately included in the development of this instrument could also be a weakness because in Indonesia the mastery of technology and the availability of technological infrastructure are still uneven (Sujarwoto and Tampubolon 2016). Given the rough technology in Indonesian regions, this instrument may not be suitable if it is used to measure the results of political education in certain areas, especially young people who are not familiar with the technology. This imbalance occurs because Indonesia is a maritime country, each region separated by the ocean (Iis Gindarsah and Priamarizki 2015).

In addition to the Indonesian archipelago, Indonesia is also a forestry country (Sujarwoto and Tampubolon 2016), whose rights make it challenge to develop technological infrastructure. Besides, the number of Indonesians who are still concentrated in Java is "Java-centric," making regional development on the island of Java faster than non-Javanese islands (Sujarwoto and Tampubolon 2016). The population of Indonesia, especially the Java region (especially East Java and Central Java) are still influenced by the old culture, and in Javanese political culture they see meetings/deliberations should be held face to face, and unethical if not done directly (Feriandi 2018).

Besides, from the age data statistics of internet usage, many users are dominated by young age (age 25 years and under), whereas for the period above it statistics show a smaller number. This can also have an impact on political participation if young citizens aged 25 years will tend to participate politically in a mix between digital and direct. While the above age tends to use direct participation, and avoid technology. Another weakness of this instrument is that it is likely to lead to quite ambiguous results if the respondent is over 25 years old.
During this time, lecturers have difficulty in measuring the level of student political participation in large numbers. With this instrument, lecturers will be assisted, and learning time will become more efficient. This instrument also has shortcomings, one of which is too many items that allow students to fill out this questionnaire. With all the advantages of this instrument, it is hoped that the teacher/lecturer can obtain data on student participation in politics. So the teacher can judge whether the results are in line with the goals of citizenship education or not

\section{Conclusions}

This research has successfully developed an instrument that can be used by teachers to measure the learning outcomes of civic education in the form of student-based political participation. During this time, teachers only measure the output of civic education in a cognitive and limited by classrooms. Besides, this instrument is expected to complement and update other political participation measurement instruments that previously existed, such as Putnam, 2000; Brady, Verba \& Schlozman, 1995. This instrument has gone through several processes such as expert testing after being judged to be suitable for use by experts, and then the results are tested in a limited class. Class test results are limited in validity and reliability using the Rasch model analysis. Therefore this instrument can be used to measure student political participation appropriately.

\section{REFERENCES}

\section{Books}

[1] Gall, M. D., Gall, J. P., \& Borg, W. R. (2003). Educational research: An introduction (7th ed.). In Boston, MA: A \& B Publications.

[2] Grizzle, Alton; Moore, Penny; Dezuanni, Michael ;Asthana, Sanjay; Wilson, Carolyn; Banda, Fackson; Onumah, C. (2013). Policy and Strategy Guidelines. UNESCO.

[3] Junco, R., \& Mastrodicasa, J. (2007). Connecting to the Net.Generation: What higher education professionals need to know about today’s students. In Higher Education.

[4] Syed Hussein, A. (1987). Korupsi: sifat, sebab dan fungsi. jakarta: LP3ES.

\section{Journals}

[5] Altbach, P. G. (2007). Perspectives on Student Political Activism. Comparative Education. https://doi.org/10.1080/ 0305006890250110

[6] Boulianne, S. (2015). Social media use and participation: a meta-analysis of current research. Information Communication and Society, 18(5), 524-538. https://doi.org/10.1080/1369118X.2015.1008542 
[7] Donoso, S. (2016). When social movements become a democratizing force: The political impact of the student movement in Chile. Research in Social Movements, Conflicts and Change. https://doi.org/10.1108/S0163-786X 20160000039008

[8] Ha, L., Joa, C. Y., Gabay, I., \& Kim, K. (2018). Does college students' social media use affect school e-mail avoidance and campus involvement? Internet Research. https://doi.org/10.1108/IntR-11-2016-0346

[9] Henry E. Brady, S. V. and K. L. S. (1995). American Political Science Review (p. 2). p. 2. https://doi.org/10.2307 _2082425

[10] Hoskins, B. L., \& Mascherini, M. (2009). Measuring active citizenship through the development of a composite indicator. Social Indicators Research. https://doi.org/10.1007/s11205-008-9271-2

[11] Hyun, K. D., \& Kim, J. (2015). The role of new media in sustaining the status quo: online political expression, nationalism, and system support in China. Information Communication and Society, 18(7), 766-781. https://doi.org/10.1080/1369118X.2014.994543

[12] Jennings, M. K., \& Langton, K. P. (2006). Mothers Versus Fathers: The Formation of Political Orientations Among Young Americans. The Journal of Politics. https://doi.org/10.2307/2128600

[13] Kuzu, Abdullah; Odabasi, Ferhan; Gunuc, S. (2015). World Journal on Educational Technology (WJET). World Journal on Educational Technology, 5(2), 301-309. https://doi.org/10.18844/wjet.v7i3.157

[14] Neundorf, A., Niemi, R. G., \& Smets, K. (2016). The Compensation Effect of Civic Education on Political
Engagement: How Civics Classes Make Up for Missing Parental Socialization. Political Behavior, 38(4), 921-949. https://doi.org/10.1007/s11109-016-9341-0

[15] Putnam, R. D. (2016). Bowling alone: America’s declining social capital. Culture and Politics: A Reader, 223-234. https://doi.org/10.1007/978-1-349-62397-6

[16] Samsuri. (2010). Transformasi Gagasan Masyarakat Kewargaan (Civil Society) Melalui Reformasi Pendidikan Kewarganegaraan Di Indonesia. Retrieved from http://eprints.uny.ac.id/1005/1/Transformasi_Gagasan_Mas yarakat_Kewargaan_\%28Civil_Society\%29_MELALUI_R EFORMASI_PENDIDIKAN_KEWARGANEGARAAN_ DI_INDONESIA.pdf

[17] Skoric, M. M., Zhu, Q., Goh, D., \& Pang, N. (2016). Social media and citizen engagement: A meta-analytic review. New Media and Society, 18(9), 1817-1839. https://doi.org/10.1177/1461444815616221

[18] Talò, C., \& Mannarini, T. (2015). Measuring Participation: Development and Validation the Participatory Behaviors Scale. Social Indicators Research, 123(3), 799-816. https://doi.org/10.1007/s11205-014-0761-0

[19] Vettehen, P. G. J. H., Hagemann, C. P. M., \& Van Snippenburg, L. B. (2004). Political knowledge and media use in the Netherlands. European Sociological Review, 20(5), 415-424. https://doi.org/10.1093/esr/jch035

[20] Yasmin, I. (2013). DAKWAH MULTIKULTURAL DI INDONESIA Studi Pemikiran dan Gerakan Dakwah Abdurrahman Wahid A. Pendahuluan Undang-Undang Dasar 1945 Pasal 29 ayat 2 menjamin kebebasan beribadah sesuai dengan agama dan keyakinannya itu. Namun kendala . Dakwah yang dilakukan. XIII, 481-500. 